\title{
BIOCHEMICAL FEATURES OF ORGANIC EXTRACTIVES FROM Eucalyptus AND Corymbia WOODS USING ETHANOL AS A SOLVENT
}

\author{
Kelvin Techera Barbosa ${ }^{1}$
}

https://orcid.org/0000-0001-9894-703X

Andrey Pereira Acosta ${ }^{2}$

https://orcid.org/0000-0002-5074-3772

Henrique Romer Schulz ${ }^{1}$

https://orcid.org/0000-0002-8162-7723

Ivandra Ignes de Santi ${ }^{3}$

https://orcid.org/0000-0002-7423-2053

Rafael de Avila Delucis ${ }^{1}$

https://orcid.org/0000-0002-3657-9216

Rafael Beltrame ${ }^{I}$

https://orcid.org/0000-0001-6352-0052

Darci Alberto Gatto ${ }^{1, \text { }}$

https://orcid.org/0000-0002-6805-3243

\begin{abstract}
This study aims to evaluate chemical characteristics, antioxidant and antibacterial activities of organic compounds extracted from three Eucalyptus wood and Corymbia maculate wood using ethanol as a solvent. To obtain the ethanolic extracts, $15 \mathrm{~g}$ of a powdered wood sample was mixed with $150 \mathrm{~mL}$ of ethyl alcohol 99 $\%$ PA by constant mechanical stirring, which was further magnetically mixed at $60{ }^{\circ} \mathrm{C}$ for $24 \mathrm{~h}$. The extractives were analyzed utilizing percent yield, Fourier-transform infrared spectrum, inhibitory index (measured after antimicrobial tests), antioxidant activity, and condensed tannins content. The Eucalyptus dunnii extract showed the highest percent yield. The infrared spectra of all the extractives presented similar profiles, with remarkable bands ascribed to the presence of lipophilic extracts, sterols, fatty acids, and other hydroxylated substances, such as carbohydrates and phenolic compounds. In all cases, the higher the concentration of the

\footnotetext{
${ }^{1}$ Federal University of Pelotas, Postgraduate Program in Materials Science and Engineering, Pelotas, Rio Grande do Sul, Brazil. ${ }^{2}$ Federal University of Rio Grande do Sul, Postgraduate Program in Metallurgical and Materials Mining Engineering, Porto Alegre, Rio Grande do Sul, Brazil.

${ }^{3}$ Federal University of Pelotas, Postgraduate program in Biochemistry and Bioprospecting, Pelotas, Rio Grande do Sul, Brazil.

•Corresponding author: gattodarci@gmail.com

Received: 22.04.2020 Accepted: 30.05.2021
} 
extractive was, the higher the antioxidant activity was. The antioxidant activity of Eucalyptus saligna extract stood out since overcame that of the positive control (ascorbic acid). Regarding the condensed tannins content, that extract from Eucalyptus grandis excelled.

Keywords: Chemical characteristics, condensed tannins, natural extractives, ethanol extraction, infrared.

\section{INTRODUCTION}

Wood is composed of structural macromolecules of high molecular weight, namely cellulose, hemicellulose, and lignin. Aside of them, extractives are low molecular weight substances from wood. They are often hydrophobic or lipophilic secondary metabolites and do not influence in the tree growth (Saha Tchinda et al. 2018).

The amount and composition of the wood extractives may vary in function of both radial and axial position in the wooden trunk. Moreover, factors associated with the forest also play significant roles, such as conditions related to both tree growth and wood storage (Saha Tchinda et al. 2018). Some wood extractives are soluble in both water and neutral organic solvents and, besides of that, most of them are located in bark (Morais et al. 2005).

According to Valette et al. (2017), the wood extractives are biosynthetized in trees to avoid injuries attributed to biotic (like fungi and insects) and abiotic (like rain, sunlight, wind, among other) agents. Other authors also reported strong correlations between the content of some wood extractives and the wood durability (Kirker et al. 2015, Pometti et al. 2009).

Eucalyptus-based woods present several types of extractives, including essential oils, fatty acid esters, as well as small amounts of inorganic substances (Santos et al. 2016). The essential oils from Eucalyptus woods are widely applied in chemical, cosmetic, and pharmaceutic industries (Albuquerque et al. 2017). The high added value of these compounds also may encourage researches on their production and characterization.

Extractives and essential oils obtained from plants are important sources of natural antioxidants (Hayat et al. 2010, Luna et al. 2010). Some recent studies reported secondary metabolites in the composition of some wood extractives, such as phenols (Jiang et al. 2017), terpenoids (Andrew et al. 2013), and flavonoids (Takahashi et al. 2004). Yamakoshi et al. (1992) and Nakayama et al. (1990) affirmed that extractives obtained from Eucalyptus macrocarpa and Eucalyptus perriniana were effective against the proliferation of some Gram-positive bacteria (namely Staphylococcus aureus and Bacillus subtilis). Moreover, Takahashi et al. (2004) studied extractives obtained from Eucalyptus leaves and flavonoids from Corymbia maculate wood and reported great performances against the growth of microbes and fungi.

For $\mathrm{Wu}$ et al. (2019), a feasible use of a wood extractive must be done after an effective and cheap extraction process. Ethanol is a commonly used solvent for obtaining several compounds from wood and other vegetable sources, such as extractives and/or essential oils (Hofmann et al. 2015). The ethanol soluble compounds from wood include fatty acid esters, long-chain alcohols, steroids, phenolic compounds, and glycosides (Sjöström and Alén 1998, Gullichsen and Paulapuro 1999, Sun and Sun 2002, Morais et al. 2005). This solvent can be obtained from renewable sources (like sugar cane) using well-known and cheap routes. This is also commonly combined with other organic solvents, like methanol and benzene, which may allow an improved extraction yield or even a selective extraction of particular substances (Abdul Mudalip et al. 2013, Peng et al. 2017).

This study aimed to evaluate chemical features and both the antioxidant and antibacterial activities of ethanol extractives obtained from three Eucalyptus woods and a Corymbia maculate wood.

\section{MATERIALS AND METHODS}

\section{Raw materials and ethanol extractions}

Fifteen 22-28-year-old exotic trees from Eucalyptus dunnii, Eucalyptus saligna, Eucalyptus grandis, and Corymbia maculate were felled in homogeneous forests located in Tapes/Brazil. Wood flakes cut from the sapwood of each specie were crushed until pass through a 40 mesh sieve and be retained in a 60 mesh sieve. 
A high purity ethanol solution (99\%) was purchased from Sigma Aldrich. $15 \mathrm{~g}$ of powdered wood sample and $150 \mathrm{~mL}$ of ethanol were placed into $250 \mathrm{~mL}$ Erlenmeyer and kept under magnetic stirring at $60{ }^{\circ} \mathrm{C}$ for $24 \mathrm{~h}$. After that, the solvent was evaporated using a Heidolph Rotary Evaporator (Laborota 4002 equipment) and then the flask was hermetically closed and stored under $-4^{\circ} \mathrm{C}$ for further analyses. Yield of the ethanol extraction was calculated according to TAPPI T 204 cm-97 (1997), as shown in Equation 1. Besides, chemical groups were evaluated by Attenuated Total Reflection-Fourier transform infrared spectroscopy (ATR-FTIR), in which 32 scans were performed at the $4000 \mathrm{~cm}^{-1}$ to $600 \mathrm{~cm}^{-1}$ range, $4 \mathrm{~cm}^{-1}$ resolution, and $2 \mathrm{~mm} \cdot \mathrm{s}^{-1} \mathrm{scanner}$ velocity, Equation 1.

$$
Y=\left(\frac{m_{e}-m_{f}}{m_{f}}\right) \times 100
$$

Where: $\mathrm{Y}$ is the percent yield, $\mathrm{m}_{\mathrm{e}}$ is the mass of the flask plus the evaporated extract, $\mathrm{m}_{\mathrm{f}}$ is the mass of the flask, and $\mathrm{m}_{\mathrm{w}}$ is the mass of the wood sample.

\section{Antimicrobial activity}

\section{Test organisms}

Antimicrobial activity was evaluated using gram-positive standard strains from Staphylococcus aureus (ATCC 25923) and Enterococccus faecalis (ATCC 51299), as well as gram-negative standard strains from Escherichia coli (ATCC 25922) and Salmonella typhimurium (ATCC 14028). These microorganisms were provided by the Oswaldo Cruz Foundation (FIOCRUZ). The evaluated strains were kept in Mueller-Hinton agar at $4{ }^{\circ} \mathrm{C}$ and reactivated prior to the antimicrobial evaluation.

The antimicrobial assays with these bacteria were carried out following the broth microdilution method, indicated by Clinical and Laboratory Standards Institute (CLSI 2018). Extractives were diluted in a 0,5\% dimethyl sulfoxide (DMSO) solution and then placed into 96-well microplates (Kasvi ${ }^{\circledR}$ ), reaching concentrations that ranged from $0,0078 \mathrm{mg} \cdot \mathrm{mL}^{-1}$ to $1 \mathrm{mg} \cdot \mathrm{mL}^{-1}$. $100 \mu \mathrm{L}$ of the DMSO-based solution was used as emulsifier to control the overall sterility and a mixture of DMSO and extractive (ratio of 1:1) was used to control the microbial growth. The bacteria were suspended in a $0,9 \%$ saline solution until reach $0,5 \mathrm{McF}$ arland standard. For that, the optical density was accessed using a UV-VIS spectrophotometer adjusted at $630 \mathrm{~nm}$ wavelength until reach an absorbance of $0,08-0,1$ range. Then, the bacterial solution was adjusted to a final concentration of $3 \mathrm{E} 4$ colony-forming unit $\mathrm{mL}^{-1}$ and the microplates were incubated at $37^{\circ} \mathrm{C}$ for $24 \mathrm{~h}$. Afterwards, a $20 \mathrm{~mL}$ of $0,02 \%$ Resazurin (acquired from Sigma Aldrich) was used to reveal the microbial growth in each well. The bacteria were indicated in pink colour and its minimal inhibitory concentration (MIC) was determined.

\section{Antioxidant activity}

The antioxidant activity was determined using 2,2-diphenyl-1-picrylhydrazyl (DPPH) as free radial, following that methodology described by Brand-Williams et al. (1995). Variable concentrations of each extractive were progressively incorporated in a $300 \mathrm{~mL}$ of a methanol-DPPH solution with $2,7 \mathrm{~mL}$ of methanol and incubated for $15 \mathrm{~min}$ in darkness. After that, a UV-VIS spectrum was obtained in a UV-M51 equipment (Bel Ptotonics brand) adjusted for a wavelength of $517 \mathrm{~nm}$. Both a reference sample and two control samples were also prepared and measured. The latter one had $2,7 \mathrm{~mL}$ of methanol and $300 \mu \mathrm{L}$ of DPPH, while both ascorbic acid and rutin (Vetec brand) were used as control samples at the following concentrations: 1,0 mg.mL-1, 0,5 mg.mL-1, 0,25 mg.mL-1 and 0,15 mg.mL-1. All analyses were performed in triplicate. Inhibition of the DPPH radical at different extract concentrations was calculated using Equation 2.

$$
\% \text { Inhibition }=\left(\frac{\mathrm{A}_{\mathrm{DPPH}}-\left(\mathrm{A}_{\text {extract }}-\mathrm{A}_{\mathrm{Blank}}\right)}{\mathrm{A}_{\mathrm{DPPH}}}\right) \times 100
$$

Where: $A_{D P P H}$ is the absorbance of the DPPH radical without samples, $A_{\text {Extract }}$ is the absorbance of extracts mixed with DPPH radical and $\mathrm{A}_{\text {Blank }}$ is the absorbance of ethanol.

\section{Condensed tannins content}

The condensed tannins content was determined according to the vanillin method, described by Morrison et al. (1995). Firstly, a vanillin solution was prepared using equal volumes of $1 \mathrm{~g}$ of vanillin in $100 \mathrm{~mL}$ of 
methanol and $8 \mathrm{~mL}$ of concentrated $\mathrm{HCl}$ in $100 \mathrm{~mL}$ of methanol. This solution was incorporated with $0.1 \mathrm{~mL}$ of extractive sample (with a concentration of $50 \mathrm{mg} \cdot \mathrm{mL}^{-1}$ ) and $0,9 \mathrm{~mL}$ of methanol. Then, it was left in water bath for $20 \mathrm{~min}$ and the absorbance was read at $500 \mathrm{~nm}$. All analyses were performed in triplicate and the corrected spectra were converted to catechin equivalents from standard curves (Missio et al. 2017).

\section{Statistical analyses}

The data were arranged in a completely randomized design. Normality of the data and homogeneity of variances were verified by the Shapiro-Wilk and Levene tests, respectively. Whenever the null hypothesis was rejected, a Fisher test (at a confidence level of $95 \%$ ) was performed to compare the means.

\section{RESULTS AND DISCUSSION}

The studied wood species presented a wide range regarding the values of yields of ethanol extractions (Table 1), which are in agreement with a previous work by Gomide et al. (2010), that reported that the main chemical compounds from wood may vary among genders, species, parts from a same tree, as well as they are affected by microclimatic factors, soil conditions, tree age, and so on.

Table 1: Values of yields of ethanol extractives for the Eucalyptus and Corymbia maculate woods.

\begin{tabular}{|c|c|c|c|c|}
\hline & $\begin{array}{c}\text { Eucalyptus } \\
\text { grandis }\end{array}$ & $\begin{array}{c}\text { Eucalyptus } \\
\text { saligna }\end{array}$ & $\begin{array}{c}\text { Eucalyptus } \\
\text { dunnii }\end{array}$ & $\begin{array}{c}\text { Corymbia } \\
\text { maculate }\end{array}$ \\
\hline $\begin{array}{c}\text { Yield of } \\
\text { extractives (\%) }\end{array}$ & 2,87 & 1,64 & 4,64 & 1,00 \\
\hline
\end{tabular}

The Eucalyptus dunnii presented the highest yield of extractives, which is ascribed to some of its intrinsic features, like anatomical, chemical and macroscopic properties. The obtained values for yield of extractives were higher than those reported by Silvério et al. (2006). These authors compared different solvents applied for extractions performed with a Eucalyptus grandis wood and reported the following yields: 2,17\%, 0,53\%, $0,55 \%$, and $2,48 \%$, which are respective to extractions with acetone, chloroform, dichloromethane, and an ethanol:toluene (1:2) mixture.

Figure 1 presents infrared spectra for all extractives, in which prominent peaks were found at $1040 \mathrm{~cm}^{-1}$, $1089 \mathrm{~cm}^{-1}$, and $1386 \mathrm{~cm}^{-1}$, which represent C-O bonds. A remarkable slope was visualized at $2978 \mathrm{~cm}^{-1}$, which represents $\mathrm{C}-\mathrm{H}$ bonds. The peak at $3326 \mathrm{~cm}^{-1}$ appears in all the spectra and can be ascribed to $\mathrm{O}-\mathrm{H}$ bonds from some alcohols (like $\beta$-sitosterol) commonly found in wood extractives. This also indicates that probably other hydroxylated compounds may be present, like phenolic groups (Gullichsen and Paulapuro 1999, Morais et al. 2005). Similarly shaped spectra were reported by Abdul Mudalip et al. (2013), who carried out an elucidative study on hydrogen bonds from a pure ethanol solution.

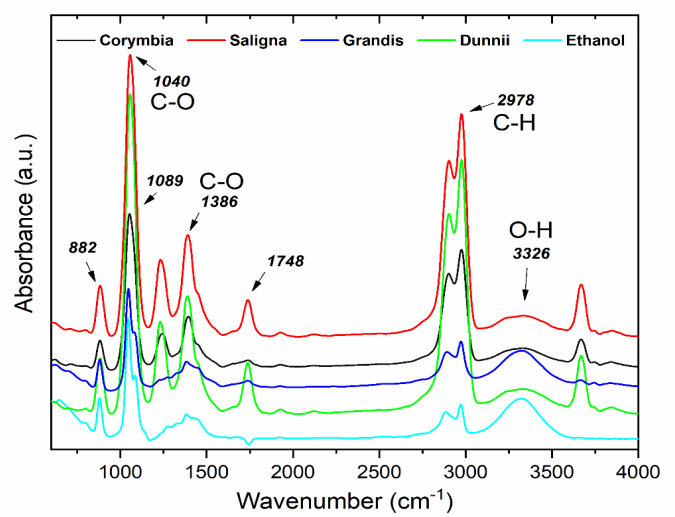

Figure 1: Infrared spectra for the Eucalyptus and Corymbia maculate woods, as well as the ethanol. 
The above mentioned spectra show peaks at $2984 \mathrm{~cm}^{-1}, 2978 \mathrm{~cm}^{-1}, 2971 \mathrm{~cm}^{-1}, 2967 \mathrm{~cm}^{-1}, 2899 \mathrm{~cm}^{-1}, 2897$ $\mathrm{cm}^{-1}$, and $2879 \mathrm{~cm}^{-1}$ correspondent to $\mathrm{C}-\mathrm{H}$ stretching, as well as $\mathrm{CH}, \mathrm{CH} 2$, and $\mathrm{CH} 3$ groups commonly found in aliphatic compounds, like fatty acids, fatty esters, and long-chain alcohols. Silverstein et al. (2002) found the same organic compounds and associated them to peaks at $2954 \mathrm{~cm}^{-1}, 2919 \mathrm{~cm}^{-1}$, and at $2850 \mathrm{~cm}^{-1}$. Other minor peaks at $1748 \mathrm{~cm}^{-1}, 1741 \mathrm{~cm}^{-1}$, and $1735 \mathrm{~cm}^{-1}$ are associated to $\mathrm{C}=\mathrm{O}$ bonds from esters (Sjöström and Alén 1998).

Figure 2 presents the different \% inhibition values of the extracts from Eucalyptus and Corymbia maculate in function of their concentrations. The E. saligna extract showed the greatest inhibition of the DPPH radical, followed by the extract of Corymbia maculate, E. dunnii and E. grandis. Regarding the positive control, E. saligna extract showed greater inhibition than ascorbic acid (except at the concentration of $0,125 \mathrm{mg} \cdot \mathrm{mL}^{-1}$ ), and in relation to the positive control rutin, all extracts showed greater inhibition in all concentrations. Also, the extractive from the Eucalyptus saligna presented a higher inhibition than the ascorbic acid, which may be attributed to its high amounts of both phenolic and hydroxyl groups.

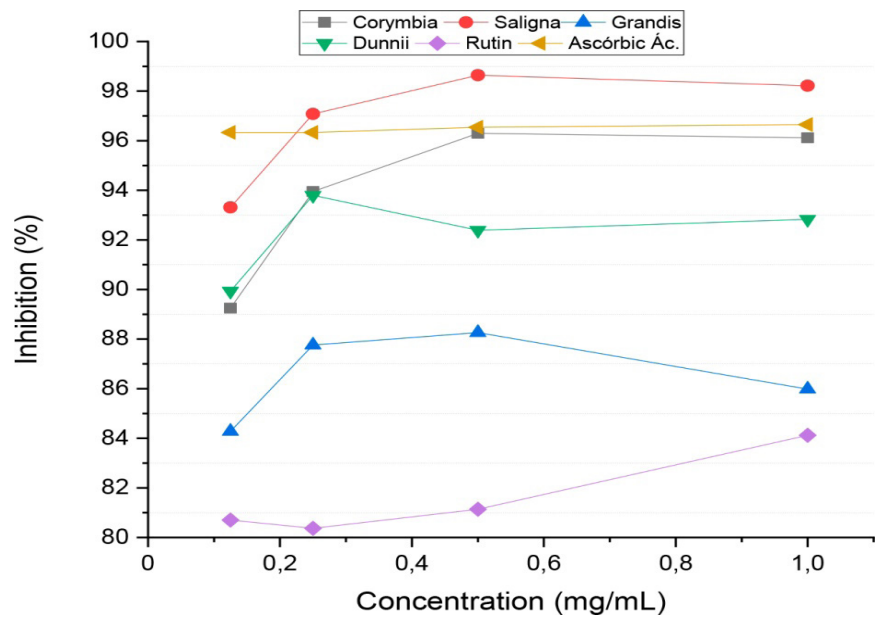

Figure 2: Minimal inhibitory concentration (antioxidant activity) values for the Eucalyptus and Corymbia maculate woods, as well as the positive controls (rutin and ascorbic acid).

Schumack et al. (2018) ascribed significant inhibitory actions to commercial essential oils extracted from Eucalyptus ssp. woods against two bacteria, namely E. coli and $S$. aureus. Regarding the same bacteria, Estanislau et al. (2001) reported similar results for essential oils extracted from both Eucalyptus grandis wood and Eucalyptus saligna wood. These essential oils were obtained by hydro-distillation and differ from those extracts studied here since wood extractives obtained by ethanolysis do not encompass essential oils (Silveira et al. 2012).

It is expected that those extractives with high contents of phenolic, fatty acids, and steroids may present high antioxidant activities. Chang (2000) and (Gomes and Canhoto 2003) reported phenolic compounds for similar wood species. Bio-based antioxidants can replace synthetic antioxidants, when equivalent or superior inhibitions of enzymatic lipid oxidation are reached (Bandoniene and Murkovic 2002). Natural antioxidants can act as inhibitors against free radicals, chelators, and oxygen scavengers and these compounds include flavonoids, phenolic acids, terpenes, tocopherols, phospholipids, and polyfunctional organic acids (Gómez 2003, Ribeiro 2007). Wood extractives with these substances are known due to their antioxidant, anti-inflammatory, anticarcinogenic and antimicrobial characters (Hras et al. 2000).

The extractives from Eucalyptus grandis wood presented the highest condensed tannin content, followed in a decreasing order by Eucalyptus saligna wood, Corymbia maculate wood, and Eucalyptus dunni wood (Table 2). That result for the Eucalyptus grandis wood indicates its high potential for particular applications, when certain features are needed, such as antibacterial, antiviral and protein-binding (Salminen 2018, Zeller 2019). The condensed tannin content is directly related to the amount of phenolic groups. In plants, condensed tannins are obtained by liquid-solid extractions and are composed of sugars, proteins, lipids and some minor phenolic compounds (Brown et al. 2017). 
Table 2: Values of condensed tannins contents for ethanol extractives of the Eucalyptus and Corymbia maculate woods.

\begin{tabular}{|c|c|c|c|c|}
\hline & $\begin{array}{c}\text { Eucalyptus } \\
\text { grandis }\end{array}$ & $\begin{array}{c}\text { Eucalyptus } \\
\text { saligna }\end{array}$ & $\begin{array}{c}\text { Eucalyptus } \\
\text { dunnii }\end{array}$ & $\begin{array}{c}\text { Corymbia } \\
\text { maculate }\end{array}$ \\
\hline $\begin{array}{c}\text { Condensed tannins } \\
\text { content }(\%)\end{array}$ & 58,62 & 15,91 & 0,35 & 0,53 \\
\hline
\end{tabular}

\section{CONCLUSIONS}

Among the wood species, the Eucalyptus dunnii wood presented the highest extractives content after the ethanol extractions. All the wood extractives yielded such infrared spectra, which were similar to lipophilic extractives, like sterols, fatty acids, and other hydroxylated substances, such as some carbohydrates and phenolic compounds. The antioxidant activities were directly related to the extractives content and the Eucalyptus saligna wood stood out, since its inhibition was higher than that of the ascorbic acid. The wood extractives showed a great potential related to the production of condensed tannins, especially the Eucalyptus grandis wood. On the other hand, there were no promise results regarding the reported antimicrobial activities and, in this sense, we recommend further studies dealing with higher concentrations of wood extractives.

\section{ACKNOWLEDGEMENTS}

This work was supported by scholarships provided by the Coordination for the Improvement of Higher Education Personnel (CAPES).

\section{REFERENCES}

Abdul Mudalip, S.K.; Abu Bakar, M.R.; Adam, F.; Jamal, P. 2013. Structures and Hydrogen Bonding Recognition of Mefenamic Acid Form I Crystals in Mefenamic Acid/Ethanol Solution. International Journal of Chemical Engineering and Applications 4(3): 124-128. https://dx.doi.org/10.7763/IJCEA.2013.V4.277

Albuquerque, C.J.B.; Silva, S.M.; Luz, J.M.Q.; Zandonadi, C.H. 2017. Consortium of Eucalyptus with forage sorghum in semiarid of Minas Gerais State. Cienc Rural 47 (11). https://dx.doi.org/10.1590/0103$8478 \mathrm{cr} 20160939$

Andrew, R.L.; Keszei, A.; Foley, W.J. 2013. Intensive sampling identifies previously unknown chemotypes, population divergence and biosynthetic connections among terpenoids in Eucalyptus tricarpa. Phytochemistry 94: 148-158. http://dx.doi.org/10.1016/j.phytochem.2013.05.002

Bandoniene, D.; Murkovic, M. 2002. On line HPLC-DPPH screening method for evaluation of radical scavenging phenols extracted from apples (Malus domestica L). J Agr Food Chem 50 (9): 2482-2487. https://dx.doi.org/10.1021/jf011475s

Brand-Williams, W.; Cuvelier, M.E.; Berset, C. 1995. Use of a free radical method to evaluate antioxidant activity. LWT - Food Sci Technol 28(1): 25-30. https://dx.doi.org/10.1016/S0023-6438(95)80008-5

Brown, R.H.; Mueller-Harvey, I.; Zeller, W.E.; Reinhardt, L.; Stringano, E.; Gea, A.; Hardcastle, E.E. 2017. Facile Purification of Milligram to Gram Quantities of Condensed Tannins According to Mean Degree of Polymerization and Flavan-3-ol Subunit Composition. J Agr Food Chem 65(36): 8072-8082. http://dx.doi.org/10.1021/acs.jafc.7b03489

Chang, R. 2000. Análise dos compostos fenólicos da madeira do E. grandis e do E. urophilla do triângulo mineiro. MSc. Thesis, Federal University of Uberlândia, UFU. Uberlândia, Brazil. https://repositorio.ufu.br/ handle/123456789/27011

Clinical and Laboratory Standards Institute. CLSI. 2018. Methods for Dilution Antimicrobial Susceptibility Tests for Bacteria That Grow Aerobically. Approved Standard - eleven Edition. CLSI document M07. https://clsi.org/standards/products/microbiology/documents/m07/

Estanislau, A.A.; Barros, F.A.S.; Peña, A.P.; Santos, S.C.; Ferri, P.H.; Paula, J.R. 2001. Composição química e atividade antibacteriana dos óleos essenciais de cinco espécies de Eucalyptus cuItivadas em Goiás. Rev Bras Farmacogn 11(2): 95-100. http://dx.doi.org/10.1590/S0102-695X2001000200005 
Gomes, F.; Canhoto, J.M. 2003. Micropropagation of Eucalyptus nitens Maiden (Shining gum). In Vitro Cell Dev-Pl 39: 316-321. http://dx.doi.org/10.1079/IVP2002376

Gómez, M.E.L.D.B. 2003. Modulação da composição de ácidos graxos poliinsaturados ômega 3 de ovos e tecidos de galinhas poedeiras, através da dieta. I. Estabilidade oxidativa. PhD. Thesis, University of São Paulo, USP/FCF. São Paulo, Brazil. http://dx.doi.org/10.11606/T.9.2003.tde-02062003-150007

Gomide, J.L.; Fantuzzi Neto, H.; Regazzi, A.J. 2010. Análise de critérios de qualidade da madeira de eucalipto para produção de celulose kraft. Rev Arvore 34(2): 339-344. http://dx.doi.org/10.1590/s010067622010000200017

Gullichsen, J.; Paulapuro, H. 1999. Forest prod. (3) chemistry. Per Stenius (Ed.): Espoo, Finland. https://www.puunjalostusinsinoorit.fi/en/shop/vol-3-forest-products-chemistry/.

Hayat, Z.; Cherian, G.; Pasha, T.N.; Khattak, F.M.; Jabbar, M.A. 2010. Oxidative stability and lipid components of eggs from flax-fed hens: effect of dietary antioxidants and storage. Poultry Sci 89(6): 1285-1292. https://dx.doi.org/10.3382/ps.2009-00256

Hofmann, T.; Nebehaj, E.; Stefanovits-Bányai, É.; Albert, L. 2015. Antioxidant capacity and total phenol content of beech (Fagus sylvatica L.) bark extracts. Ind Crop Prod 77: 375-381. https://doi.org/10.1016/j. indcrop.2015.09.008

Hras, A.R.; Hadolin, M.; Knez, Z.; Bauman, D. 2000. Comparison of antioxidative and synergistic effects pf rosemary extract with $\alpha$-tocopherol, ascorbyl palmitate and citric acid in sunflower oil. Food Chem 71(2): 229-233. http://dx.doi.org/10.1016/S0308-8146(00)00161-8

Jiang,P.;Xiong,J.;Wang,F.;Grace,M.H.;Lila,M.A.;Xu,R.2017. $\alpha$-Amylaseand $\alpha$-GlucosidaseInhibitory Activities of Phenolic Extracts from Eucalyptus grandis $\times$ E. urophylla Bark. JChem-NY 1. Article ID 8516964 . http://dx.doi.org/10.1155/2017/8516964

Kirker, G.T.; Bishell, A.B.; Lebow, P.K. 2015. Laboratory Evaluations of Durability of Southern Pine Pressure Treated With Extractives From Durable Wood Species. J Econ Entomol 109(1): 259-266. http://dx.doi.org/10.1093/jee/tov286

Luna, A.; Lábaque, M.C.; Zygadlo, J.A.; Marin, R.H. 2010. Effects of thymol and carvacrol feed supplementation on lipid oxidation in broiler meat. Poultry Sci 89: 366-370. http://dx.doi.org/10.3382/ps.200900130

Missio, A.L.; Tischer, B.; Santos, P.S.B.; Codevilla, C.; Menezes, C.R.; Barin, J.S.; Haselein, C.R.; Labidi, J.; Gatto, D.A.; Petutschnigg, A.; Tondi, G. 2017. Analytical characterization of purified mimosa (Acacia mearnsii) industrial tannin extract: single and sequential fractionation. Sep Purif Technol 186: 218225. https://dx.doi.org/10.1016/j.seppur.2017.06.010

Morais, S.A.L.; Nascimento, E.A.; Melo, D.C. 2005. Análise da madeira de Pinus oocarpa parte I: estudo dos constituintes macromoleculares e extrativos voláteis. Rer Arvore 29(3): 461-470. http://dx.doi.org/10.1590/S0100-67622005000300014

Morrison, I.M.; Asiedu, E.A.; Stuchbury, T.; Powell, A.A. 1995. Determination of lignin and tannin contents of cowpea seed coats. Annals of Botany 76(3): 287-290. https://dx.doi.org/10.1006/anbo.1995.1097

Nakayama, R.; Murata, M.; Homma, S.; Aida, K. 1990. Antibacterial Compounds from Eucalyptus perriniana. Agr Biol Chem Tokyo 54(1): 231-232. http://dx.doi.org/10.1080/00021369.1990.10869881

Peng, W.; Li, D.; Zhang, M.; Ge, S.; Mo, B.; Li, S.; Ohkoshi, M. 2017. Characteristics of antibacterial molecular activities in poplar wood extractives. Saudi J Biol Sci 24(2): 399-404. https://dx.doi.org/10.1016/j. sjbs.2015.10.026

Pometti, C.L.; Vilardi, J.C.; Cialdella, A.M.; Saidman, B.O. 2009. Genetic diversity among the six varieties of Acacia caven (Leguminosae, Mimosoideae) evaluated at the molecular and phenotypic levels. Plant Syst Evol 284(3-4): 187-199. http://dx.doi.org/10.1007/s00606-009-0244-y 
Ribeiro, E.T. 2007. Emprego de técnicas de extração a alta e baixa pressão para obtenção de polifenóis antioxidantes do subproduto agroindustrial da maçã. MSc. Thesis, Federal University of Santa Catarina, UFSC/ PPEA. Santa Catarina, Brazil. http://repositorio.ufsc.br/xmlui/handle/123456789/90218

Saha Tchinda, J.B.; Ndikontar, M.K.; Fouda Belinga, A.D.; Mounguengui, S.; Njankouo, J.M.; Durmaçay, S.; Gerardin, P. 2018. Inhibition of fungi with wood extractives and natural durability of five Cameroonian wood species. Ind Crop Prod 123: 183-191. http://dx.doi.org/10.1016/j.indcrop.2018.06.078

Salminen, J.P. 2018. Two-Dimensional Tannin Fingerprints by Liquid Chromatography Tandem Mass Spectrometry Offer a New Dimension to Plant Tannin Analyses and Help To Visualize the Tannin Diversity in Plants. J Agr Food Chem 66 (35): 9162-9171. https://dx.doi.org/10.1021/acs.jafc.8b02115

Santos, R.; Carneiro, A.; Vital, B.; Castro, R.; Vidaurre, G.; Trugilho, P.; Castro, A. 2016. Influência das propriedades químicas e da relação siringil/guaiacil da madeira de eucalipto na produção de carvão vegetal. Cienc Florest 26(2): 657-669. http://dx.doi.org/10.5902/1980509822765

Schumack, K.D.S.P.; Barbosa, A.C.D.A.; Santos, L.D.; Santos, T.G.; Lima, C.P. 2018. Atividade antimicrobiana dos óleos essenciais de Thymus vulgaris L., Eucalyptus citriodora Hook e illicium verum hook $\mathrm{f}$. Anais do EVINCI-UniBrasil 3(1): 244-244. https://portaldeperiodicos.unibrasil.com.br/index.php/anaisevinci/ article/view/3472

Silveira, J.; Busato, N.; Costa, A.; Costa Jr, E. 2012. Levantamento e análise de métodos de extração de óleos essenciais. Enciclopédia Biosfera 8(15) Goiânia, Brazil. http://www.conhecer.org.br/enciclop/2012b/ ciencias $\% 20$ exatas $\% 20 \mathrm{e} \% 20 \mathrm{da} \% 20$ terra/levantamento $\% 20 \mathrm{e} \% 20$ analise.pdf.

Silvério, F.O.; Barbosa, L.C.A.; Gomide, J.L.; Reis, F.P.; Veloso, D.P. 2006. Metodologia de extração e determinação do teor de extrativos em madeiras de eucalipto. Rev Arvore 30(6): 1009-1016. http://dx.doi.org/10.1590/S0100-67622006000600016

Silverstein, R.M.; Bassler, G.C.; Morrill, T.C. 2002.Identificação espectrométrica dos compostos orgânicos. 6. ed. Rio de Janeiro: Guanabara, Rio de Janeiro, Brazil.

Sjöström, E.; Alén, R. 1998. Analytical methods in wood chemistry pulping and papermaking. Springer-Verlag: Berlin Heidelberg, Germany. https://dx.doi.org/10.1007/978-3-662-03898-7

Sun, X.; Sun, R. 2002. Spectroscopic characterization of extractives isolated with MTBE from straws. Tappi J 2(11): 23-26.

Takahashi, T.; Kokubo, R.; Sakaino, M. 2004. Antimicrobial activities of eucalyptus leaf extracts and flavonoids from Eucalyptus maculate. Lett Appl Microbiol 39(1): 60-64. http://dx.doi.org/10.1111/j.1472765X.2004.01538.X

TAPPI. 1997. T $204 \mathrm{~cm}-97$. Solvent extractives of wood and pulp. 4 p. https://imisrise.tappi.org/TAPPI/ Products/01/T/0104T204.aspx.

Wu, Y.; Sun, Y.; Yang, F.; Zhang, H.; Wang, Y. 2019. The Implication of Benzene-Ethanol Extractive on Mechanical Properties of Waterborne Coating and Wood Cell Wall by Nanoindentation. Coatings 9(7): 449. https://dx.doi.org/10.3390/coatings9070449

Valette, N.; Perrot, T.; Sormani, R.; Gelhaye, E.; Morel-Rouhier, M. 2017. Antifungal activities of wood extractives. Fungal Biol Rev 31(3): 113-123. http://dx.doi.org/10.1016/j.fbr.2017.01.002

Yamakoshi, Y.; Murata, M.; Shimizu, A.; Homma, S. 1992. Isolation and Characterization of Macrocarpals B-G Antibacterial Compounds from Eucalyptus macrocarpa. Biosci Biotech Bioch 56(10): 1570-1576. http://dx.doi.org/10.1271/bbb.56.1570

Zeller, W.E. 2019. Activity, Purification, and Analysis of Condensed Tannins: Current State of Affairs and Future Endeavors. Crop Sci 59(3): 886. https://doi.org/10.2135/cropsci2018.05.0323 